ÖZ

\title{
Demir Minerali: Fonksiyonları, Gıda İşlemenin Biyoyararlılığı Üzerine Etkileri ve Biyoaktif Bileşenler ile İnteraksiyonları
}

\author{
Ceren İNCE ${ }^{1}, \quad$ Özlem ÇAĞINDI ${ }^{2 *}$
}

İnsan metabolizmasında iz miktarlarda bulunan mikro minerallerden biri olan demirin önemli ve çeşitli görevleri bulunmakta, eksikliğinde bazı belirtiler görülebilmekte ve hastalıklara yol açabilmektedir. Gıda matriksinin yapısında bulunan bu mikro mineralin diğer besin ögeleri ile etkileşimi ve gıda işleme teknolojilerinin etkilerinin değerlendirilmesi önemlidir. Biyoerişilebilirliği ve biyoyararlılı̆̆ 1 ise, diyetteki miktar ve formlarının yanı sıra, diğer bileşenlerle aralarındaki sinerjik ve antagonistik etkileşimlerine de bağlıdır. Geleneksel gıda işlemenin, mikro mineral içeriği üzerinde olumsuz etkileri bulunmasından dolayı ısıl olmayan yeni işleme teknolojilerine yönelim olmuştur. Böylelikle, günümüzde yeni işleme teknolojilerinin in vitro sindirim metotlarıla biyoerişilebilirliği üzerine etkileri tespit edilmektedir. Bu çalışmada, demirin vücuttaki fonksiyonları, emilim mekanizması, gıda işlemenin demirin biyoerişilebilirliği ve biyoyararlılı̆̆ üzerine etkileri, diğer besin ögeleri ve biyoaktif bileşenlerle interaksiyonları incelenerek derlenmiştir.

Anahtar Kelimeler: Biyoyararlılık, demir minerali, gıda proses, interaksiyon

\section{Iron Mineral: Functions, Effects of Food Processing on Bioavailability and Interactions with Bioactive Components}

\begin{abstract}
Iron, which is one of the trace amounts of micro minerals in human metabolism, has important and various functions, some symptoms may be seen in its deficiency and may cause diseases. The interaction of this micro mineral in the structure of the food matrix with other nutrients and the evaluation of the effects of food processing technologies is important. Bioaccessibility and bioavailability depend on the amount and forms of the diet, as well as their synergistic and antagonistic interactions with other ingredients. Since traditional food processing has negative effects on micro mineral content, there has been a trend towards new non-thermal processing technologies. Thus, nowadays the effects of new processing technologies on bioavailability with in vitro digestion methods are determined. In this study, the functions of iron in the body, the mechanism of absorption, the effects of food processing on the bioaccessibility and bioavailability of iron were compiled by examining their interactions with other nutrients and bioactive components.
\end{abstract}

Keywords: Bioavailability, iron mineral, food processing, interaction

ORCID ID (Yazar sırasına göre)

0000-0001-9931-2327, 0000-0002-6436-9208

Yayın Kuruluna Geliş Tarihi: 26.09.2020

Kabul Tarihi: 20.12.2020

${ }^{1}$ Manisa Celal Bayar Üniversitesi Fen Bilimleri Enstitüsü, Gıda Mühendisliği Anabilim Dalı, Manisa, Türkiye

${ }^{2}$ Manisa Celal Bayar Üniversitesi Mühendislik Fakültesi, Gıda Mühendisliği Bölümü, Manisa, Türkiye

*E-posta: ozlem.cagindi@cbu.edu.tr 


\section{Demir Minerali: Fonksiyonları, Gıda İşlemenin Biyoyararlılığı Üzerine Etkileri ve Biyoaktif Bileşenler ile İnteraksiyonları}

\section{Giriș}

Vücuda alınan besin ögelerinin yaklaşık \%0.20.3 'ünü oluşturan mineral maddelerin metabolizmada önemli görevleri bulunmaktadır. Günlük diyette bulunan sodyum $(\mathrm{Na})$, kalsiyum $(\mathrm{Ca})$, magnezyum $(\mathrm{Mg})$, potasyum $(\mathrm{K})$, fosfor $(\mathrm{P})$, klor $(\mathrm{Cl})$, kükürt $(\mathrm{S})$ makro minerallerdir.

Demir (Fe), çinko $(\mathrm{Zn})$, bakır $(\mathrm{Cu})$, iyot $(\mathrm{I})$, manganez $(\mathrm{Mn})$, flor $(\mathrm{F})$ ise mikro minerallerdir (Güzel-Seydim, 2016).

"Gizli açlık" olarak da bilinen mikro besin yetersizliği, dünyanın birçok yerinde önemli bir sağlık sorunudur. Demir, çinko, iyot gibi mikro minerallerin ve diğer mikro besinlerin eksikliğiyle ortaya çıkan gizli açlık özellikle çocukları, ergenlik yaşındaki gençleri, hamile ve emziren bayanları etkilemektedir. Dünya nüfusunun yarısından fazlası, yaklaşık 3 milyar insan mikro besin ögelerince yetersiz beslenmektedir (Frossard ve ark., 2000; Welch ve Graham, 2004; Murgia ve ark., 2012). Mikro minerallerden olan demirin yetersizliği dünyada en yaygın görülen beslenme bozukluklarından biridir (Ortiz-Monasterio ve ark., 2007). Dünya nüfusunun \%60'ından fazlasında demir eksikliği bulunmaktadır. Demir eksikliği özellikle gelişmekte olan ülkelerde yaygın olarak görülen, yetersiz beslenmenin bir sonucu olarak gelişmiş ülkelerde de ciddi bir halk sağlığ 1 sorunu olmaya devam etmektedir (Pavord ve ark., 2012). Demir yetersizliğinin görülmesinin en belirgin nedeni diyetlerde demir bakımından zengin olan hayvansal kaynaklı gıdalara yeterince ağırlık verilmemesidir. Vücuttaki demir yetersizliğinde hemoglobin gibi hem proteinlerinin ve kofaktör (Muria ve ark., 2012; Gregory ve ark., 2017).

Demir, çinko ve kalsiyum eksikliklerinde düşük biyoyararlılık özellikle önem kazanmakta ve sağlanan miktar beslenme gereksinimlerini karşılamak için yeterli olmamaktadır. Biyoyararlılığın vücutta sağlanabilmesi için minerallerin emilebilir olmas1 ve gastrointestinal sistemde biyolojik olarak erişilebilir olması gerekir. Minerallerin biyolojik olarak erişilebilirliği, diyet kaynaklarına, emilim inhibitörlerinin varlığına bağlıdır. Gıda olarak demire sahip olan enzimlerin azalmasıyla anemi veya kırmızı kan hücrelerinin miktarında bir düşüş olmaktadır. Demir, oksijen taşınması ve depolanması ve büyüme, bağışıklık, kas aktivitesi, kemik gücü ve sinir sistemi ile ilgili diğer birçok metabolik fonksiyon için gereklidir. Vücut dokularına düşük oksijen iletimine ve demir içeren enzimlerin azalmış aktivitesine bağlı olarak zayıflık, yorgunluk, bilişsel verimlilikte düşme ve konsantre olma zorlukları yaşanmaktadır (Camaschella, 2015). Gidalardan sindirilmiş demir formunun kullanımının yetersizliğine bağlı olarak çocuklarda büyüme, bilişsel gelişimde yetersizlik, gebelik döneminde daha fazla rahatsızlık ve yetișkin insanlarda daha düşük verimle çalıșma sorunları ortaya çıkmaktadır. Hamilelik sırasında demir eksikliği anemisi düşük doğum ağırlığı, prematürite riski ve anne ve çocuk ölümleri ile ilişkilendirilmiştir. Demir eksikliğini önlemek için diyette optimum miktarda demir yönetiminin sağlanması gerekmektedir. Gıdada bulunan bileşenlerin demir formunun doğru kombinasyonu demir biyoyararlılığını arttırmada ve inhibitörlerin etkileşimini kontrol altına almada oldukça önem taşımaktadır (Camaschella, 2015; Cardoso ve ark., 2019).

Gıdaların zenginleştirilmesi çalışmalarında insanlarda fazlasiyla görülen mikro besin eksikliği sebebiyle mineraller oldukça yaygın olarak kullanılmaya başlanmıştır. Demirin diyetten sağlama kaynaklarını arttırma yaklaşımları; gıda takviyesi, zenginleştirme, diyette çeşitlilik ve biyofortifikasyon çalışmalarını içermektedir

işlemede, biyoyararlılık üzerinde başlica belirleyici etkilerden biri de besin maddelerindeki biyoaktif bileşiklerin biyoerişilebilirliğidir (Drago ve Valencia, 2004; Altıner ve Şahan, 2016).

$\mathrm{Bu}$ derlemede, mikro mineral olan demirin vücuttaki fonksiyonları, emilim mekanizması, gıda işlemenin demir mineralinin biyoerişilebilirliği ve biyoyararlılığ etkisi, diğer besin ögeleri ve biyoaktif bileşenlerle interaksiyonları incelenmiştir 


\section{Demir Minerali: Fonksiyonları, Gıda İşlemenin Biyoyararlılığı Üzerine Etkileri ve Biyoaktif Bileşenler ile İnteraksiyonları}

Yaşlılarda anemi, düşük yaşam kalitesi ve fiziksel işlevlik ile ilișkilendirilmiștir (Thein ve ark., 2009; Scholl, 2011; Allali ve ark., 2017). Diğer yandan demir mineralinin vücutta fazlalığ1, siroz, kardiyovasküler hastalık, tip 2 diyabet ve kanser gibi çeşitli hastalıklarla iliş̧kili olduğu gözlemlenmiştir (Vaquero ve ark., 2017).

\section{Demir Mineralinin Vücuttaki Fonksiyonları}

İnsan ve hayvan beslenmesinde esansiyel bir mikro mineral olan demir; oksijenin kırmızı kan hücreleri tarafından taşınımı, depolanması ve kullanımı ile redoks potansiyelleri gibi birçok biyolojik fonksiyonda görev almaktadır. Diyetle alınan demir, hem demir $\left(\mathrm{Fe}^{+2}\right.$, hayvansal kaynaklardan) ve hem olmayan demir $\left(\mathrm{Fe}^{+3}\right.$, bitkisel kaynaklardan) olmak üzere iki formda sağlanmaktadır. Hem demir, et ürünleri, yumurta, balık ve tavukta bulunur. Bitkisel esaslı gida maddelerinde bulunan demirin ana formu, hem olmayan demirdir. Demir yetersizliğinde çocuklarda öğrenme kabiliyetinde azalma görülmektedir. Hem olmayan demirin absorpsiyonu, tam tahillarda, mercimeklerde ve fındıklarda bulunan fitik asit tarafından inhibe edilmektedir. Düşük pH, askorbik asit varlığında hem olmayan demir emilimi artıș göstermektedir. Diğer yandan hem demirin emilimi hem olmayan demirin emilimine göre 23 kat daha fazladır. Kișinin beslenme durumu besin ögesinin vücuda alımını etkilemekte ve demir depoları azalmış ise emilimde artış gözlenmektedir. Demir mineralinin gidada bulunan diğer besin ögeleri ile etkileşimi emilimini etkilemektedir. Askorbik asit ile demirin birlikte alımı demir emilimini arttırmaktadır. Buna ek olarak, çay, kahve, kırmızı şaraplar ve çeşitli tahıllar, sebzeler ve baharatlarda bulunan tanen ve klorojenik asitler gibi polifenoller de demir emilimini inhibe etmektedir (Hunt, 2003; Gharibzahed ve Jafari, 2017). İnsanların büyüme, gelişme ve sağlıklarını olumlu yönde etkileyen önemli mikro besin ögelerinden biri olan demirin yetersizliğine de gelișmiș ve gelișmekte olan ülkelerde sıkça rastlanmaktadır. Ayrıca, demir diğer besin ögeleri ile karşıllaştırıldığında vücutta fazla miktarda biriktiğinde toksisite tehlikesi olan bir mineraldir (Yip, 2001; Vasconcelos ve Grusak, 2006). Günlük alınması gereken demir minerali; erkeklerde $1 \mathrm{mg}$, çocuk, ergen ve kadınlarda 2-3 mg, hamilelerde 3-4 mg olarak belirlenmiştir (FAO/WHO, 2002; Güzelcan ve El, 2011). Çizelge 1'de demir minerali gida kaynakları ve vücuttaki fonksiyonları yer almaktadır.

Çizelge 1. Demir minerali gıda kaynakları ve vücuttaki fonksiyonları (Güzelcan ve El, 2011; BlancoRojo ve Vaquero, 2019; Kumar ve ark., 2020)

\begin{tabular}{|c|c|c|c|}
\hline Gıda Kaynakları & Fonksiyonları & $\begin{array}{c}\text { Eksikliğinde Görülen } \\
\text { Hastalıklar }\end{array}$ & $\begin{array}{c}\text { Emilimi etkileyen } \\
\text { faktörler }\end{array}$ \\
\hline $\begin{array}{c}\text { Et ürünleri } \\
\text { Tahıl ürünleri } \\
\text { Baklagiller } \\
\text { Yeşil yapraklı sebzeler } \\
\text { Yumurta } \\
\text { Kurutulmuş meyveler }\end{array}$ & $\begin{array}{l}\text { Hemoglobin kan } \\
\text { proteininin üretiminde } \\
\text { ATP üretimi, hücre } \\
\text { solunumu } \\
\text { Yeni hücrelerin yapımı }\end{array}$ & $\begin{array}{c}\text { Kansızlık } \\
\text { Yorgunluk } \\
\text { Öğrenme kabiliyetinde } \\
\text { azalma } \\
\text { Yara iyileşmesinde } \\
\text { gecikme }\end{array}$ & $\begin{array}{c}\text { Arttıran: } \\
\text { Kırmızı kan hücre } \\
\text { sayısında artış } \\
\text { Mide salgıları } \\
\text { Vücuttaki demir } \\
\text { depolarının azalması } \\
\text { veya tükenmesi } \\
\text { Askorbik asit (C } \\
\text { vitamini) } \\
\text { Azaltan: } \\
\text { Tanenler } \\
\text { Fitatlar, fitik asit } \\
\text { Anti asitler }\end{array}$ \\
\hline
\end{tabular}




\section{Demir Minerali: Fonksiyonları, Gıda İşlemenin Biyoyararlılığı Üzerine Etkileri ve Biyoaktif Bileşenler ile İnteraksiyonları}

\section{Demir Mineralinin Emilim Mekanizması}

Demir mineralinin eksikliği dünyanın dört bir yanındaki sağlık sorunlarına önemli ölçüde yol açtığından bu mineralin emilimiyle ilgili mekanizmaların açıklığa kavuşturulması önem taşımaktadır. Gastrointestinal sistemde sindirim işleminden sonra gidalarda bulunan mineraller ince bağırsakta emilmektedir. Örneğin, demir ince bağırsağın ilk kısmındaki duodenumda absorbe edilmektedir. Duodenumda yeterli miktarda demir absorbe edilmesi hayati önem taşıyor olmasına rağmen, bu mineral önemli miktar1 diyetten absorbe edilememektedir. Demirin emiliminde düşük $\mathrm{pH}$, askorbik asit, sitrik asit, çok değerlikli metal-organik kompleksler, diğer mikro besin ögeleriyle etkileşimi gibi faktörler rol oynamaktadır (Windisch, 2002; Walczyk ve von Blanckenburg, 2002; Güzelcan ve El, 2011; Blanco-Rojo ve Vaquero, 2019). Ayrica, gastrik asit salgisinda bulunacak olan anti asitler ve ilaveten bazı şelat ajanlarının varlığı, demir emiliminde azalmaya, vücutta demir eksikliği bozukluklarına neden olmaktadır. Vücutta demir mineralinin yetersiz alımıla anemi oluşmaktadır. Bununla birlikte, demirin eliminasyonu için fizyolojik bir yol bulunmadığı için yüksek miktarlarda alımı tehlikeli olabilmektedir (Fuqua ve ark., 2012; Saini ve ark., 2016).

Hemoglobin üretimi için iyonik demirin mukozal hücrelerde emilmesi, asidik koşullar altında aktif geçiş vasıtasıyla yapılmaktadır. Feferritin depolayan demir kompleksleri, bu hücrelerdeki iyonik demir ve ferritin proteini arasında bağlanarak oluşturulmaktadır. $\mathrm{Fe}^{+3}$ duodenumda bulunan ferriduktaz aktivitesi ile $\mathrm{Fe}^{+2}$ ye indirgenmektedir. Demirin, iki değerlikli metal ve bir proton ile birlikte enterosit içerisine taşınımı gerçekleşmektedir (Saini ve ark., 2016). Enterosit içindeki demir, hem diyetteki hem de vücuttaki demir yüklerine dayalı karmaşık bir hücre programlamasına bağlı olarak iki ana yoldan birini izlemektedir. (I) Enterosit içerisindeki demir, ferritin içerisine dahil edildiğinde bloke edilir ve bu nedenle kan içine taşınmaz. Demir, enterosit öldüğünde veya döküldüğünde kaybolmaktadır. (II) Demir, membranda bulunan bir taşıyıcı tarafından
Sınırlayıcı koşullar altında enterositten dışarıya verilir ve daha sonra tüm vücuda ulaşması için demir taşıyıcısına bağlanır. Diğer yandan, demirin hem formu basit şekilde hemoglobin/miyoglobin alımıla absorbe edilmektedir. $\mathrm{Bu}$ şartlardaki bozulmamış hem formunun endotel hücrelerinin aktif taşınmasıyla bağırsaktaki enterosit tarafından alındığ anlaşılmaktadır. Fe, enterosit içerisinde serbest bırakılır ve emilen inorganik demir gibi yol izler. Demir hem formunun bozulmamış bazı molekülleri dolaşıma taşınmaktadır (Miret ve ark., 2003).

Vücut sistemindeki demir metabolizmas1, hepsidinin transmembran proteini "ferroportin" ile etkileşimi yoluyla ayarlanabilmektedir. Heposit, enterosit, makrofaj ve hepatosit membranlarında ferroportin varlığının inaktive edilmesi, yeniden kullanımı ve depolama ile normal koşullar altında demirin absorpsiyonunu önemli ölçüde azaltmaktadır. Demir bakımından zenginleştirilmiş gıdaların tüketildiği halde $\mathrm{Fe}$ emiliminin azalmasının nedeni, iltihaplı sitokinlerin akut faz reaksiyonlarına maruz kalan hepsidin sentezinin artışına bağlı iltihaplanmalar olduğu görülmektedir. Hepsidinin artan konsantrasyonlarında ferroportini parçalayan demir düzenleyici hormon demirin bağırsak hücrelerinden plazmaya geçiş yolunu bloke etmektedir. $\mathrm{Bu}$ doğal bağışıklık yanıtı, Fe emilimini azaltarak patojenlerin etkilerini sınırlandırmaktadır. Aksine, karaciğer hepsidin üretiminin azalması ile yüksek demir salınım oran1, demir absorpsiyonunda bir artış ile elde edilmektedir (Rossi, 2005; Blanco-Rojo ve Vaquero, 2019; Kumar ve ark., 2020).

\section{Gıda İşlemenin Demirin Biyoerişilebilirliği ve Biyoyararlılı̆̆ı Üzerine Etkileri}

Biyoerişilebilirlik; alınan gıdanın sindirildikten sonra, içerisindeki besin öğelerinin gidanın matriksinden çıkabilen ve ince bağırsakta emilim için hazır olan miktarı olarak tanımlanır. Biyoyararlılık; tüketilen gidanın sindirildikten sonra içerisindeki besin ögelerinin ve biyoaktif bileşiklerin emilmesi, hücrelere ulaşması ve burada normal metabolik ve fizyolojik fonksiyonlar için kullanılması veya depolanması olarak tanımlanmaktadır (Fernández-García ve 


\section{Demir Minerali: Fonksiyonları, Gıda İşlemenin Biyoyararlılığı Üzerine Etkileri ve Biyoaktif Bileşenler ile İnteraksiyonları}

ark., 2009). Demir biyoyararlılığ1, metabolik fonksiyonlar için kullanılmak üzere emilen ve hücrelerde kullanılan demir miktarı olarak ifade edilmektedir (Lucca ve ark., 2001). Biyoyararlılıkta en önemli faktörlerden biri, bazı besin öğelerinin sindirimini ve emilimini inhibe eden bileşenlerin varlı̆̆gdır. Besin ögesinin biyoyararlılığı, besin ögesi emilimini azaltan veya arttıran faktörler ve/veya diyetin tamamı ile arasındaki dengeye bağlıdır. Biyoyararlılıkta besin ögesinin kimyasal formu önemli rol oynamaktadır. Hem demirin, hem olmayan demire göre biyoyararlılığ 1 daha yüksektir. Hem demiri, doğrudan mukoza membranlarındaki reseptörlerce alındığg için daha etkili olmaktadır. Demirin biyoyararlılı̆̆ 1 hem demir için \%15-35 arasında, hem olmayan demir için ise \%2-20 aralığında değişim göstermektedir (Güzelcan ve El, 2011).

Gidaların raf ömrünü uzatmak, mikroorganizmaları kontrol altına almak veya etkisiz hale getirmek için yüksek sıcaklıkta teknolojik işlemler uygulanabilmektedir. Gıda işleme, besin maddelerindeki biyoaktif bileşiklerin biyoerişilebilirliği ve biyoyararlılığ üzerinde etkili faktörlerden biridir. Isıl ve 1s1l olmayan çeşitli işleme teknolojileri (tavlama, öğ̈̈tme, çimlendirme, fermentasyon vb.) mineral biyoyararlılığını etkilemektedir. Modern işleme tekniklerinin (yüksek basınç, ultrason vb.), geleneksel işlemlere kıyasla gıdanın mikro ve makro mineral içeriğine etkilerinin daha az olduğu görülmektedir. Diğer yandan, gıda işleme teknolojisi ile birlikte, gıdalardaki antinutrisyonel ögelerin miktarı azalarak mikro besin ögelerinin erişilebilirliği artırılabilmektedir. Son y1llarda ürün kalitesini ve güvenirliğini arttırmak, raf ömrünü uzatmak hedeflenirken gida bileşenlerinin besleyici, fonksiyonel özelliklerinin de korunması yönünde isıl olmayan işleme teknolojileri uygulanmaya başlanmıştır. Böylelikle bu bileşenlerin hem stabilitesi hem de biyoerişilebilirlikleri göz önünde bulundurulmuş olmaktadır (Roldán-Marín ve ark., 2009). Is1l işlem, proteinlerin ve nişastanın sindirilebilirliğini artırır. Fitat, sıcaklığa bağl1 olarak degrade olduğunda nişasta jelatinizasyonunu, demir, çinko, kalsiyum biyoyararlılı̆̆ını artırabilmektedir. Gidalara uygulanan mekanik işlemler (öğütme, ruşeym alma vb.) sonucunda pirinç, buğday ve misırda mineral madde içeriği azalmasına karşılık demir, çinko, kalsiyum biyoyararlılığının arttığı görülmüştür. Mikrobiyal fermentasyon işleminin fitatı azalttığ 1 , fermentasyon ortamında açığa çıkan organik asitler, çözünür ligandların yanı sıra hem olmayan demir, çinko biyoyararlılığını $\operatorname{arttırdığ~} 1$ bildirilmektedir (Gibson ve ark., 2006).

Çimlendirme işlemi fonksiyonel bileşenleri arttırmak için etkili bir yöntem olarak yaygın olarak kullanılmaktadır. Bu işlemle vitaminler, mineraller ve fenolik bileşikler gibi bazı besin ögelerinin miktarı artarken, fitik asit ve fitat miktarı azalmaktadır. Yapılan bir çalışmada fitat hidrolizini sağlayan fitaz aktivitesinin arttığ 1 çimlendirme işlemi uygulanmış ve çinko, demir, kalsiyum, magnezyum emiliminin arttığı, ancak baz1 baklagillerin (Vicia fava) polifenol içeriğinin azaldığı gözlemlenmiştir (Gibson ve ark., 2006). Farklı bileşenler arasındaki sinerjik ve antagonist etkilere bağlı olarak mineraller, antioksidanlar gibi bazı mikro besin maddelerinin serbest bırakılmasını, emilimini ve nişasta, protein gibi makro moleküllerin sindirilebilirliğini etkilemektedir (Moongngarm ve Saetung, 2010). Yapılan bir diğer çalışmada, çimlendirme ve yüksek hidrostatik basınç işlemlerinin, kahverengi pirinçteki mineral elementlerin, amino asitlerin, antioksidanların ve nişastanın in vitro biyoerişilebilirliği üzerindeki etkileri araştırılmıştır. Çimlenmiş kahverengi pirinç $37^{\circ} \mathrm{C}$ de 36 saat inkübasyona tabi tutulmuş ve daha sonra $0.1,100,300$ ve 500 MPa'da $10 \mathrm{dk}$ süreyle yüksek hidrostatik basınç işlemlerine tabi tutulmuştur. Uygulanan işlemler sonucu demirin in vitro biyolojik olarak erişilebilirliğinin azaldığı bildirilmiştir (Xia ve ark., 2017).

Buğday unu demir, çinko ve kalsiyum içermekle birlikte, besin emilimini arttırmak için zenginleştirmede kullanılmaktadır. Yapılan bir çalışmada tam buğday ununun zenginleştirilmesinde kullanılan demir bileşiklerinin, in vitro sindirim metodu ile ekmeklerde demir, çinko ve kalsiyumun biyoerişilebilirliği üzerine etkisinin saptanması 


\section{Demir Minerali: Fonksiyonları, Gıda İşlemenin Biyoyararlılığı Üzerine Etkileri ve Biyoaktif Bileşenler ile İnteraksiyonları}

amaçlanmıştır. NaFeEDTA (demirli sodyum etilen diamin tetra asetik asit), FFm (mikroenkapsüle demir fumarat), Fsm (mikroenkapsüle edilmiş demir sülfat) ve FF (demir fumarat) 4 farklı demir bileşiği kullanılmıştır. FS, FF, NaFeEDTA ve FSm gibi demir bileşiklerinin, hububat ürünlerini zenginleştirmede vücutta emilme olasılığ1 daha yüksektir. In vitro çözünürlük $(\% 44.80)$ ve diyaliz (\%46.14) metodlarına göre NaFeDTA ve FSm'nin tam buğday ununun güçlendirilmesinde en etkili demir bileşikleri olduğu tespit edilmiştir (Akhtar ve ark., 2009; Hurrell ve ark., 2010).

Kahvaltılık tahıllara kalsiyum ilâvesinin çocuklardaki kalsiyum emiliminde nasıl etki edeceği yönünde yapılan çalışmada toplam kalsiyum emiliminin, kalsiyumla zenginleştirilmiş tahıl örneğinde $215 \pm 45$ mg/gün'den $269 \pm 45 \mathrm{mg} /$ gün'e yükseldiği tespit edilmiştir. Kalsiyum ilave edilmiş ve kalsiyumca zenginleştirilmemiş tahıl örneklerinde demir absorpsiyonu benzer bulunmuş, hububat ürününe orta seviyede kalsiyum ilavesi, demir emilimini etkilemeden toplam kalsiyum emiliminde net bir artış sağlandığı gözlemlenmiştir (Abrams ve ark., 2001). Suda çözünür diyet lifindeki kazeinin inhibisyonu ile demir emiliminin etkili şekilde gerçekleştiği söylenmektedir. Yapılan bir çalışmadaki sonuçlara göre, $0.42 \mathrm{~g}$ keçi boynuzu gamının içeriğindeki kazein $(\% 0.32)$ ve peynir altı suyu proteinleri $(\% 1.45)$ ile geliştirilen formüllerin diyaliz uygulanan in vitro sindirim metodu analizinde demir absorpsiyonu açısından anlamlı bir farklılık bulunmuştur (Bosscher ve ark., 2001). Başka bir çalışmada da kazeinlere kıyasla peynir altı suyu proteinlerinin varlığında daha yüksek bir demir absorpsiyonu gözlenmiştir (Drago ve Valencia, 2004).

Farklı konsantrasyonlarda likopen, lutein ve zeaksantin karotenoidlerinin ilâvesinin insan vücudundaki demir ve kahve emilimine etkisinin incelendiği bir çalışmada ise, buğday esaslı kahvaltıya $3.6 \mathrm{mg}$ likopen, $1.8 \mathrm{mg}$ lutein ve 1.8 mg zeaksantin eklendiğinde demir emilimi sirasiyla $\% 8.1^{\prime}$ den $\% 22.5$ 'e, $\% 15.8$ 'e ve $\% 16.5^{\prime}$ e yükseldiği gözlendiği bildirilmiştir. Mısır esaslı bir kahvaltıya aynı miktarda likopen, lutein ve zeaksantin ilavesi sonucu, demir emiliminin $\% 5.4$ 'ten sirasiyla $\% 18.0, \% 12.9$ ve $\% 11.1$ oranlarında arttı̆̆1 gözlenmiştir. Lutein ve zeaksantin için benzer artış görülürken, likopen ise daha fazla etkili olduğu bildirilmiştir. Çalışmadaki karotenoidlerin, kahve ile demir emiliminin direkt engellenmesini önlemede aracı olabileceği öne sürülmüştür (Casal, 2006).

Meyve-sebze endüstrisinde portakal, misket limonu kullanılması sonucu oluşan yan ürünlerin pişirme işlemi sonrası demir mineraline etkisinin değerlendirildiği bir çalışmada in vitro biyoerişilebilirlik sindirim modellemesinde çözünürlük ve diyaliz metotları uygulanmıştır. Pişirmenin minerallerin biyolojik erişilebilirliğini etkilediğini, demirin diyaliz edilebilir fraksiyonunu artırdığı doğrulanmıştır. Çözünür ve diyalize edilebilir metotla yapılan sindirim analizlerinde minerallerin emilim yüzdesi demir için \%5.59-\%69.06 arasında değişmektedir. Toplam demir içeriği, değerlendirilen örneklerde $38.04 \mu \mathrm{g} / \mathrm{g}-362.37$ $\mu \mathrm{g} / \mathrm{g}$ değişim aralığında ve en yüksek değer misket limonunda bulunmuştur. In vitro metodundaki çözünürlük analizinde işlem görmemiş örneklerde 29.42-80.58 $\mu \mathrm{g} / \mathrm{g}$ ve pişmiş örneklerde $26.03-191.39 \mu \mathrm{g} / \mathrm{g}$ aralığında değişim gösterdiği kaydedilmiştir. Diyaliz ile yapılan analizde demir konsantrasyonlar1, 19.17$38.04 \mu \mathrm{g} / \mathrm{g}$ ve pişmiş örneklerde 19.13-95.98 $\mu \mathrm{g} / \mathrm{g}$ değerleri arasında bulunmuştur. En düşük demir konsantrasyon değeri pişirme işlemi uygulanmış portakalda bulunurken, en yüksek demir konsantrasyonu değeri pişirilmiş misket limonunda görülmüştür. Diyaliz ile yapılan analizdeki demir miktarı önerilen günlük alımın (RDI) \%68'ine karş1lık geldiği bildirilmektedir (Silva ve ark., 2017).

Demirin biyolojik olarak erişilebilirliğini etkileyebilecek faktörlerden biri pektin gibi çözünebilir liflerin varlığıdır. Çözünür liflerin demirin biyolojik olarak erişilebilirliğinde de etkili olduğu gözlemlenmiştir. Bununla birlikte yapılan bir çalışmada demirin biyolojik olarak erişilebilirliğinin artması ile çözünebilir liflerin azalması arasında doğrudan bir ilişki kurulamamıştır (Kyomugasho ve ark., 2017). 


\section{Demir Minerali: Fonksiyonları, Gıda İşlemenin Biyoyararlılığı Üzerine Etkileri ve Biyoaktif Bileşenler ile İnteraksiyonları}

Misır unlarında demir emilimi in vitro metodunda çözünürlük analizi ile \%7.5 diyaliz ile $\% 3.5$ oranında elde edilmiştir ve unlardaki fitat gibi antinutrisyonel faktörlerin azalmasinın demirin biyoyararlılığını önemli ölçüde etkilemediği gözlenmiştir. Bununla birlikte, selülaz ve ksilanaz ile işleme tabi tutulan unların, diyaliz uygulanan demir fraksiyonunda bir artışa sahip olduğu söylenmektedir. $\mathrm{Bu}$ da, liflerin degrade olmasının, demirin biyolojik erişilebilirliğini artırdığını göstermektedir (Baye ve ark., 2015).

Çeşitli çalışmalarda süt ürünleri, tahıllar, et ve sebze ürün grupları değerlendirilmiştir. In vitro metot ile yapilan analizde demir, yulafta $\% 12$, kahverengi pirinçte \%85, nohutta \%20.90, bezelyelerde \%18.56, kırmızı barbunya içinde $\% 15.53$, süt tozunda $\% 85.29$ ve tavukgöğsünde $\% 14.47$ olarak tespit edilmiştir. İnek sütünde çözünebilen demir fraksiyonu için \%46.17'den $\% 54.74$ 'e kadar ve diyaliz edilebilen fraksiyon için \%40.73'ten \%50.44'e kadar değişen oranlarda değerler bulunduğu bildirilmiștir (Perales ve ark., 2006; Singh ve ark., 2016).

Amarant, kinoa, karabuğday tahıllarının iki farklı pișirme metodu (haşlama, buharla pişirme) ile demir miktarındaki değişimlerin incelendiği bir çalışmada pişirme işleminden sonra amarantın demir içeriğinin en yüksek olduğu bildirilmiştir. Çiğ ve haşlama işleminden sonraki kinoanın demir miktarı, buharda pişirme yöntemi sonrasında elde edilen demir miktarından daha düşük bulunduğu saptanmıştır, Çalışmada kullanılan üç farklı tahıl içerisinde hașlama ișleminden sonra karabuğdayın demir içeriğinde önemli ölçüde azalma tespit edilmiştir (Mota ve ark., 2016).

Yüksek hidrostatik basınç işleminin uygulandığı bir çalışmada elmalardaki in vitro metotta çözünürlük yöntemi ile analiz edilen demir biyolojik olarak erişilebilirliğinin, $500 \mathrm{MPa} / 2$ $\mathrm{dk}, 500 \mathrm{MPa} / 8 \mathrm{dk}$ ve $500 \mathrm{MPa} / 10 \mathrm{dk}$ ile işlem gören numuneler ile işlem görmemiş numuneler arasında önemli fark gözlenmemişken 500 $\mathrm{MPa} / 4 \mathrm{dk}$, işlem görmeyen örneklere göre demir biyoerişilebilirliğinin istatistiksel olarak daha yüksek olduğu bildirilmiștir $(\mathrm{P}<0,05)$ (BrionesLabarca ve ark., 2011a). Başka bir araştırmada, yüksek hidrostatik basınç ile $500 \mathrm{MPa} / 4 \mathrm{dk}$ ișlem görmüş algarrobo tohumları, işlem görmemiş tohumlara kıyasla hiçbir fark göstermediği bildirilmektedir $(\mathrm{P}>0,05)$. Bu sonuçlar, demirin biyolojik olarak erişilebilirliğinin gida matrisinde bulunan bileșenlerle yakından ilişkili olduğunu düşündürmektedir (Briones-Labarca ve ark., 2011b).

Geleneksel pişirmenin bir sonucu olarak gida matriksinin yumuşaması ve proteine bağlı minerallerin salınması nedeniyle demir mineralinin biyoerişilebilirliğinin artırılabileceği ve/veya okzalatlar, fitatlar, taninler ve fenolik bileşikler gibi çözünürlük inhibitörlerinin mineral içeriklerini modifiye edilebileceği düşünülmektedir (Viadel ve ark., 2006). Bu durum, hazır mercimeklerde basınçlı pişirmede, işlenmiş tahıllarda mikrodalgada, bakliyatlarda geleneksel pişirme prosesiyle demirin biyoerişilebilirliğinde azalma olduğu bildirilmektedir (Hemalatha ve ark., 2007a; Pereira ve ark., 2016). Yapılan araștırmaların çoğunda bakliyat, tahıl, yeşil yapraklı sebzeler ve bebek formulasyonları gibi gidalardaki demirin biyoerişilebilirliğinde azalma olduğu gözlenmiştir.

Geleneksel pişirme işleminden önceki 1slatma işlemi sırasında baklagillerde bulunabilecek minerallerin suda kaybolabilmesi sebebiyle demirin biyoerişilebilirliğinin olumsuz etkilendiği bildirilmiştir (Pereira ve ark., 2016). Elma ve algarrobo tohumlarında demir mineralinin biyoerişilebilirliğinde artış gözlemlenmesi bitki hücresi duvarlarının bozularak g1da matriksinde oluşan değişikliklere bağlanmaktadır. Bununla birlikte, aynı gidalarda farklı sindirim yöntemleri (çözünürlük ve diyaliz) ve farklı işleme süreleri uygulandığında bu demir biyoerişilebilirliğinin azaldığı görülmüştür (Briones-Labarca ve ark., 2011a; Briones-Labarca ve ark., 2011b). Çizelge 2'de gidalara uygulanan farklı işlemlerin in vitro sindirim metodu sonucunda demir biyoerişilebilirliği etkisi üzerine yapılan bazı çalışmalar yer almaktadır. 


\section{Demir Minerali: Fonksiyonları, Gıda İşlemenin Biyoyararlılığı Üzerine Etkileri ve Biyoaktif Bileșenler ile İnteraksiyonları}

Çizelge 2. Gıda işlemenin demirin biyoerişilebilirliğine etkisi

\begin{tabular}{|c|c|c|c|c|}
\hline Gida & İşlem & $\begin{array}{l}\text { In vitro } \\
\text { Sindirim } \\
\text { Metodu }\end{array}$ & $\begin{array}{c}\text { Demir } \\
\text { Biyoerişilebilirliği } \\
\text { Üzerine Etkisi }\end{array}$ & Referans \\
\hline Kuru fasulye & \multirow{2}{*}{ Geleneksel pişirme } & \multirow{2}{*}{ Diyaliz } & Azalma & \multirow{3}{*}{$\begin{array}{l}\text { (Sebastiá } \\
\text { ve ark., } \\
2001)\end{array}$} \\
\hline Nohut & & & $-*$ & \\
\hline \multirow[b]{3}{*}{ Mercimek } & Mikrodalga & Diyaliz & - & \\
\hline & Geleneksel pişirme & \multirow[b]{2}{*}{$\begin{array}{l}\text { Çözünürlük/ } \\
\text { Caco-2 } \\
\text { hücreleri }\end{array}$} & \multirow[b]{2}{*}{ Azalma } & \multirow[b]{2}{*}{$\begin{array}{l}\text { (Viadel ve } \\
\text { ark., 2006) }\end{array}$} \\
\hline & Endüstriyel proses & & & \\
\hline $\begin{array}{l}\text { Tahıllar: Pirinç, darı, } \\
\text { buğday, mısır }\end{array}$ & \multirow[b]{2}{*}{$\begin{array}{l}\text { Basınçli pişirme ve } \\
\text { mikrodalga }\end{array}$} & \multirow[b]{2}{*}{ Diyaliz } & \multirow[b]{2}{*}{$\begin{array}{c}\text { Darı, misır, nohut } \\
\text { haricinde } \\
\text { Artma }\end{array}$} & \multirow[b]{2}{*}{$\begin{array}{l}\text { (Hemalath } \\
\text { a ve ark., } \\
\text { 2007a) }\end{array}$} \\
\hline $\begin{array}{l}\text { Baklagiller: Nohut, } \\
\text { börülce, yeşil, } \\
\text { kırmızı, siyah fasulye }\end{array}$ & & & & \\
\hline Elma & $\begin{array}{c}\text { Yüksek Basınçlı Proses } \\
\left(500 \mathrm{MPa} 20^{\circ} \mathrm{C} 2,4,6,8,10\right. \\
\mathrm{dk})\end{array}$ & $\begin{array}{l}\text { Çözünürlük ve } \\
\text { Diyaliz }\end{array}$ & $\begin{array}{l}\text { Çözünürlük } 4 \mathrm{dk} \\
\text { Artma } \\
\text { Diyaliz } 8 \mathrm{dk} \text { Artma } \\
\text { Diyaliz } 4 \mathrm{dk} \\
\text { Azalma } \\
\end{array}$ & $\begin{array}{l}\text { (Briones- } \\
\text { Labarca ve } \\
\text { ark., } \\
\text { 2011a) }\end{array}$ \\
\hline $\begin{array}{l}\text { Algarrobo (Prosopis } \\
\text { chilensis) tohumlar }\end{array}$ & $\begin{array}{c}\text { Yüksek Basınçlı Pişirme } \\
\left(500 \mathrm{MPa} 20^{\circ} \mathrm{C}\right. \\
2,4,8,10 \mathrm{dk})\end{array}$ & $\begin{array}{l}\text { Çözünürlük ve } \\
\text { Diyaliz }\end{array}$ & $\operatorname{Artma}(10 \mathrm{dk})$ & $\begin{array}{l}\text { (Briones- } \\
\text { Labarca ve } \\
\text { ark., 2011) }\end{array}$ \\
\hline Bebek formülasyonları & $\begin{array}{l}\text { Geleneksel Pişirme } \\
\text { (Kaynatma) }\end{array}$ & Diyaliz & Azalma & $\begin{array}{l}\text { (Galán ve } \\
\text { Drago, } \\
\text { 2014) }\end{array}$ \\
\hline Börülce fasulyesi & $\begin{array}{c}\text { Basınçlı pişirme (4 dk, oda } \\
\text { sıcaklığı, slatılmadan önce) } \\
\text { ve devamlı kaynatma }\left(30^{\circ} \mathrm{C}\right. \\
\text { ve } 10 \mathrm{dk})\end{array}$ & Diyaliz & $\begin{array}{l}\text { Basınçlı Pişirme } \\
4 \text { dk Artma }\end{array}$ & $\begin{array}{l}\text { (Pereira ve } \\
\text { ark., 2016) }\end{array}$ \\
\hline
\end{tabular}

*(-): Etkisi bulunmamaktadır

\section{Demir Mineralinin Diğer Besin Ögeleri ve Biyoaktif Bileşenlerle İ̀teraksiyonları \\ Gıdada bulunan çeşitli bileşenler ince bağırsakta mineral ve iz elementlerle çözünür veya çözünemeyen kompleksler oluştururlar. Besin ögesi interaksiyonları bazı makro ve}

mikro minerallerin biyoyararlılı̆̆ını azaltmaktadır. Yapılan çalışmalarda, sitrik asit, askorbik asit, laktoz ve bazı amino asitler biyoyararlılığ1 artırıc1 etkisi olan bileşenler; fitik asit, diyet lifi ve fenolik bileşenlerin biyoyararlılığı azaltıcı bileşenler olduğu belirlenmiștir.

Polifenoller, besin ögelerine (demir vb.) bağlanarak onların biyoyarayışlılı̆̆ını azalttığı bildirilmektedir (Güzelcan ve El, 2011; Blanco-Rojo ve Vaquero, 2019). Demir biyoyararlılığında artırıcı ve azaltıcı etki gösteren başlıca inhibitörlerin detayları Çizelge 3'te gösterilmektedir. 


\section{Demir Minerali: Fonksiyonları, Gıda İşlemenin Biyoyararlılığı Üzerine Etkileri ve Biyoaktif Bileșenler ile İnteraksiyonları}

Çizelge 3. Demir biyoyararlılığında etkili başlıca ana artırıcı ve azaltıcı etki sağlayan gıda ve bileşenler (Blanco-Rojo ve Vaquero, 2019)

\begin{tabular}{|c|c|c|c|c|}
\hline Etki & Gida & Bileşen & Mekanizma & Açıklama \\
\hline \multirow[b]{2}{*}{$\begin{array}{l}\text { Artırıcı } \\
\text { etki }\end{array}$} & $\begin{array}{c}\text { Narenciye } \\
\text { meyveleri, meyve } \\
\text { suları, sebzeler }\end{array}$ & Askorbik asit & $\begin{array}{c}\text { Bağırsakta çözünür kalan } \\
\text { ve } \mathrm{Fe}^{3+} \text { 'in Fe } \mathrm{Fe}^{2+1} \text { ya } \\
\text { indirgenen çözünür } \\
\text { demir-askorbat } \\
\text { komplekslerinin } \\
\text { oluşumunda her ikisi de } \\
\text { emilimi destekler }\end{array}$ & $\begin{array}{l}\text { Askorbik asidin demir } \\
\text { emiliminde güçlü bir } \\
\text { artırıcı etkisi } \\
\text { bulunmaktadır. Ancak } \\
\text { ortamda ısı varlığında } \\
\text { kolayca } \\
\text { bozunabilmektedir. }\end{array}$ \\
\hline & $\begin{array}{l}\text { Et, balık, kümes } \\
\text { hayvanları }\end{array}$ & $\begin{array}{l}\text { Hayvansal } \\
\text { bileşenler }\end{array}$ & $\begin{array}{c}\text { Demirin sindirim } \\
\text { ürünlerine bağlanması } \\
\text { sonucu proteinlerin } \\
\text { çözünen bileşikler } \\
\text { oluşturması }\end{array}$ & $\begin{array}{l}\text { Termal proseslerden } \\
\text { etkilenmemektedir. }\end{array}$ \\
\hline \multirow{3}{*}{$\begin{array}{c}\text { Azalticı } \\
\text { etki }\end{array}$} & $\begin{array}{l}\text { Tam taneli tahıl, } \\
\text { kuruyemiş, } \\
\text { baklagiller }\end{array}$ & Fitik asit & $\begin{array}{l}\text { Bağırsakta çözünmeyen } \\
\text { demir fitat } \\
\text { komplekslerinin oluşumu }\end{array}$ & $\begin{array}{l}\text { Yüksek diyet lifi içeren } \\
\text { gidalar en önemli } \\
\text { inhibitördür. }\end{array}$ \\
\hline & Çay, kahve, kakao & Polifenoller & $\begin{array}{l}\text { Bağırsakta demir ile } \\
\text { çözünmeyen } \\
\text { komplekslerin oluşumu }\end{array}$ & $\begin{array}{c}\text { Çay polifenolleri en güçlü } \\
\text { inhibitör olarak } \\
\text { bilinmektedir }\end{array}$ \\
\hline & $\begin{array}{l}\text { İnek sütü, süt } \\
\text { ürünleri }\end{array}$ & Süt Proteini & $\begin{array}{l}\text { Tüm kazein ve } \alpha \text {-kazein } \\
\text { fosfo peptitleri, demire } \\
\text { bağlanarak emilimini } \\
\text { güçlü bir şekilde } \\
\text { engellemektedir. } \\
\text { Hem ve hem olmayan } \\
\text { demirlerin emilimi azalır. }\end{array}$ & $\begin{array}{l}\text { Peynir altı suyu proteinleri } \\
\text { inhibitör değildir. } \\
\text { In vitro testlerden ve } \\
\text { insanlarda epidemiyolojik } \\
\text { çalışmalardan elde edilen } \\
\text { sonuçlar dahilinde } \\
\text { gözlemlenmiştir. } \\
\end{array}$ \\
\hline
\end{tabular}

Bitkisel bazlı gidalarda bulunan hem olmayan demirin $(<\% 10)$ düşük emilimi nedeniyle demir biyoyararlılığ1, hayvansal gidalardaki hem demire (\%15-35) göre daha düşük biyoyararlılığ bulunmaktadır (Hurrell ve Egli, 2010). Tahillar ve baklagillerde yüksek miktarda bulunan fitik asit (fitat; inositol fosfatlar), fenolik bileşikler ve kalsiyum demirin emilimini engellemektedir (Kumar ve ark., 2010).

Mineraller, endüstriyel üretim süreçlerinde vitaminlere kıyasla yapısal olarak daha dayanıklı olmakla birlikte, gıdaların işlenmesi ve depolanması sırasında 1şık, nem, 1sı veya oksijen etkisiyle meydana gelen yeni formları vücudumuzda tolere edilememektedir. Minerallerin biyoyararlılığı sadece diyetteki seviyelerine ve formlarına değil, aralarındaki sinerjik ve antagonistik etkileşimlere de bağlıdır
(Windisch, 2002; Freeland-Graves ve ark., 2015; Cilla ve ark., 2018).

Demir ile kalsiyum arasında insan sindirim sisteminde antagonistik bir interaksiyonun bulunduğu ancak bu mekanizmanın sebebinin henüz açıklanamadığ 1 ifade edilmektedir (Deehr ve ark., 1990; Hemalatha, 2007b). Fenolik bileșiklerin demir emilimi üzerinde olumsuz etkisinin olduğunu bildirilen çalışmaların yanı sıra, olumlu etkilerinin saptandığı çalışmalar da bulunmaktadır (Cook ve ark.,1991; Hemalatha, 2007b). Çeşitli mineraller vücuda eş zamanlı alındıklarında daha fazla miktarda bulunan mineralin emiliminin daha yüksek oranlarda gerçekleştiği gözlemlenmiştir (Whittaker, 1998; Güzelcan ve El, 2011). Örneğin; demir miktarının diğer bir mikro mineral olan çinkodan fazla olduğu ortamda çinkonun emiliminin 


\section{Demir Minerali: Fonksiyonları, Gıda İşlemenin Biyoyararlılığı Üzerine Etkileri ve Biyoaktif Bileşenler ile İnteraksiyonları}

azaldı ̆̆ 1 belirtilmektedir. (Coudray ve ark., 1998; Güzelcan ve El, 2011). Yapılan çalışmalar demir minerali ile probiyotiklerin gida matriksinde birlikte kullanımının demir biyoyararlılı̆̆ını arttıracağı yönündedir (Hoppe ve ark., 2015).

Bebek mamasında bulunan beş makro ve sekiz mikro mineral miktarlarının $(\mathrm{Cd}, \mathrm{Cu}, \mathrm{Fe}, \mathrm{Mn}, \mathrm{Ni}$, $\mathrm{Pb}, \mathrm{Se}, \mathrm{Zn}$ ve $\mathrm{Ca}, \mathrm{K}, \mathrm{Mg}$, Na ve P) tespit edilerek olması gereken alt sınır değerleri karşıladığının tespit edildiği bir çalışmada, mineraller ile anne sütünde bulunan minerallerde karşılaştırılmıştır. Benzer analiz sonuçların elde edildiği tespit edilmiştir. Vejeteryan diyetlerde demir ve çinko, demir ve manganez etkileşimleri için $10 \mathrm{mg} /$ gün alındığında antagonistik etkileri olduğu bildirilmiștir. Büyüme ve gelişme için gerekli olduğundan, sadece vejetaryen diyetle beslenen bebeklerde, demirin yetersiz alımının özellikle kritik önem taşıdığı vurgulanmıştır. Bununla birlikte, bebek maması içerisinde bulunan diğer gida bileşenlerinin minerallerin biyoyararlılı̆̆ 1 üzerindeki sınırlayıcı etkileri de dikkate alınıp değerlendirilmesi gerekliliği vurgulanmıştır (Khamoni ve ark., 2017). Çizelge 4'te öğün planlamasında demir emilimini arttırmak için gerekli sinerjik etkiyi oluşturacak gida kombinasyonları ve etkileri üzerinde çalışmalar verilmiştir.

Çizelge 4. Demir biyoyararlılığı arttırmak için sinerjik etkisi olan gıdalar

\begin{tabular}{|c|c|c|c|}
\hline Tip & Kombinasyon & $\begin{array}{r}\text { Etkisi } \\
\end{array}$ & Referans \\
\hline $\begin{array}{l}\text { C vitamini açısından } \\
\text { zengin gıdaların } \\
\text { demir emilimi }\end{array}$ & $\begin{array}{l}\text { Diyetteki C vitamini } \\
\text { zengin gidalar }\end{array}$ & $\begin{array}{c}\text { Demir emilimi ve fosfat } \\
\text { arasında negatif korelasyon, } \\
\text { askorbik asit ile pozitif } \\
\text { korelasyon }\end{array}$ & $\begin{array}{l}\text { (Cook ve Reddy, } \\
\text { 2001) }\end{array}$ \\
\hline \multirow{3}{*}{$\begin{array}{l}\text { Hayvansal gidaların } \\
\text { demir emilimi }\end{array}$} & $\begin{array}{l}\text { Et ile fitat bakımından } \\
\text { zengin ögünün demir } \\
\text { emilimi } \\
\end{array}$ & $\begin{array}{l}50 \mathrm{~g} \text { ve } 75 \mathrm{~g} \text { etle demir } \\
\text { emiliminde } \% 44 \text { ve } \% 57 \text { artış }\end{array}$ & $\begin{array}{c}\text { (Boech ve ark., } \\
\text { 2003) }\end{array}$ \\
\hline & $\begin{array}{l}\text { Yüksek fitatlı diyette etin } \\
\text { demir emilimi }\end{array}$ & $\begin{array}{c}\text { Vejetatif diyetle } \\
\text { karşılaştırıldığında etten } \\
\text { gelen demir emiliminde artış }\end{array}$ & $\begin{array}{c}\text { (Kristensen ve ark., } \\
\text { 2005) }\end{array}$ \\
\hline & $\begin{array}{c}\text { Yağlı balık ile fitatca } \\
\text { zengin öğünde (fasulye) } \\
\text { demir emilimi }\end{array}$ & Demir emiliminde artış & $\begin{array}{l}\text { (Navas-Carretero } \\
\text { ve ark., 2009) }\end{array}$ \\
\hline
\end{tabular}

\section{Sonuc}

Demir eksikliği dünya çapında bir halk sağlı̆̆ sorunudur ve gidaların demir ile zenginleştirilmesi demir eksikliğini en uygun önleme stratejisi olarak görülmektedir. Gida bilimcileri olarak, gidanın makro ve mikro besin içeriğini göz önünde bulundurarak kapsamlı bir şekilde araştırılması gereken uygun işleme ve depolama metodolojilerini kullanarak daha besleyici gidaların sürdürülebilir yollarla üretilmesi oldukça önemlidir. Gıda işlemenin demirin biyoerişilebilirliği üzerindeki etkisi; proses tipi, gıda işleme parametreleri (sıcaklık, $\mathrm{pH}$, parçacık boyutu, uygulanan basınç vb.), gıda matriksi bileşimi, yapısı, bileșenlerin emilim oran1, besin ögeleri arasındaki interaksiyonları gibi farklı faktörlere bağlıdır. Gıda işleme teknikleri ile gıdadaki demir içeriğini arttırmak ve emilim inhibitörlerini azaltmak için farklı yaklaşımlar geliştirilmelidir. Proses yöntemlerinin yanında diyet bileşenleri ve fizyolojik faktörlerin de iyi anlaşılması önemlidir. Gıda işleme sırasında ve sonrasında, vücutta emilimi, demirin biyoyararlılığını belirlemektedir. Demir ve diğer elzem iz elementler arasindaki interaksiyon mekanizmalarının anlaşılması için daha fazla çalışma gereklidir. Gıdadaki demir içeriğini arttırmak ve emilim inhibitörlerini azaltmak için farklı yaklaşımlar geliştirilmelidir. Prebiyotikler, probiyotikler ve metal şelatlar gibi bazı bileşenlerin demir minerali üzerindeki etkisinin doğru bir şekilde incelenmesi gerekir. Demir minerali ile yapılan araştırma çalışmaları incelendiğinde, yüksek basınç işleminin mineralin besin ögesi bakımından stabilitesini koruyup biyoerişilebilirliğini arttırmak için en 


\section{Demir Minerali: Fonksiyonları, Gıda İşlemenin Biyoyararlılığı Üzerine Etkileri ve Biyoaktif Bileşenler ile İnteraksiyonları}

iyi seçenek olacağ birlikte, demirin biyoerişilebilirliğini sağlamak/arttırmak için uygulanan gida ișleme tekniklerinin (geleneksel pişirme, yüksek basınç,

\section{Kaynaklar}

Abrams, S. A., Griffin, I. J., Davila, P., Liang, L. (2001) Calcium fortification of breakfast cereal enhances calcium absorption in children without affecting iron absorption. The Journal of Pediatrics 139(4):522-526.

Akhtar, S., Anjum, F. M., Rehman, S. U., Sheikh, M. A. (2009) Effect of mineral fortification on rheological properties of whole wheat flour. Journal of Texture Studies 40(1):51-65.

Allali, S., Brousse, V., Sacri, A. S., Chalumeau, M., de Montalembert, M. (2017) Anemia in children: prevalence, causes, diagnostic work-up, and long-term consequences. Expert Review of Hematology 10(11):1023-1028.

Altıner, D. D., Şahan, Y. (2016) Gidaların minerallerle zenginleștirilmesine yönelik uygulamalar, Türkiye 12. Gida Kongresi, Edirne, Türkiye.

Baye, K., Guyot, J. P., Icard-Vernière, C., Rochette, I., Mouquet-Rivier, C. (2015) Enzymatic degradation of phytate, polyphenols and dietary fibers in Ethiopian injera flours: Effect on iron bioaccessibility. Food Chemistry 174: 6067.

Blanco-Rojo R., Vaquero, M. P. (2019) Iron bioavailability from food fortification to precision nutrition. A review. Innovative Food Science \& Emerging Technologies 51:126-138.

Boech, S. B., Hansen, M., Bukhave, K., Jensen, M., Sorensen, S. S., Kristensen, L. (2003) Nonheme-iron absorption from a phytaterich meal is increased by the addition of small amounts of pork meat. American Journal of Clinical Nutrition 77: 173-179.

Bosscher, D., Van Caillie-Bertrand, M., Deelstra, H. (2001) Effect of thickening agents, based on soluble dietary fiber,the availability of calcium, iron, and zinc mikrodalga, ultrason) çeşitli gıdalarda kullanımı ile ilgili çeşitli gıdalarda daha fazla araştırmaya ihtiyaç duyulmaktadır.

from infant formulas. Nutrition, 17(7-8): 614-618.

Briones-Labarca, V., Venegas-Cubillos, G., Ortiz-Portilla, S., Chacana-Okeda, M., Maureira, H. (2011a) Effects of high hydrostatic pressure (HHP) on bioaccessibility, as well as antioxidant activity, mineral and starch contents in Granny Smith apple. Food Chemistry 128(2): 520-529.

Briones-Labarca, V., Muñoz, C., Maureira, H. (2011b) Effect of high hydrostatic pressure on antioxidant capacity, mineral and starch bioaccessibility of a non conventional food: Prosopis chilensis seed. Food Research International 44(4):875-883.

Camaschella, C. (2015) Iron-deficiency anemia. New England Journal of Medicine, 372(19):1832-1843.

Cardoso, R. V. C., Fernandes, Â., GonzalézParamás, A. M., Barros, L., Ferreira, I. C. F. R. (2019) Flour fortification for nutritional and health improvement: A review. Food Research International 125:108576.

Casal, MNG. (2006) Carotenoids increase iron absorption from cereal-based food in the human. Nutrition Research, 26:340-344.

Cilla, A., Bosch, L., Barberá, R., Alegría, A. (2018) Effect of processing on the bioaccessibility of bioactive compoundsa review focusing on carotenoids, minerals, ascorbic acid, tocopherols and polyphenols. Journal of Food Composition and Analysis 68:3-15.

Cook, J.D., Dassenko, S.A., Whittaker, P. (1991) Calcium supplementation: effect on iron absorption. The American Journal of Clinical Nutrition 53:106-111.

Cook, J. D., Reddy, M. B. (2001) Effect of ascorbic acid intake on nonheme-iron absorption from a complete diet. The 


\section{Demir Minerali: Fonksiyonları, Gıda İşlemenin Biyoyararlılığı Üzerine Etkileri ve Biyoaktif Bileşenler ile İnteraksiyonları}

American Journal of Clinical Nutrition 73(1):93-98.

Coudray, C., Bousset, C., Tressol, J. C., Pépin, D., Rayssiguier, Y. (1998) Short-term ingestion of chlorogenic or caffeic acids decreases zinc but not copper absorption in rats, utilization of stable isotopes and inductively-coupled plasma mass spectrometry technique. British Journal of Nutrition 80(6):575-584.

Deehr, M.S., Dallal G.E., Smith K.T., Taulbee J.D., Dawson- Hughes B. (1990) Effects of different calcium sources on iron absorption in postmenopausal women. The American Journal of Clinical Nutrition 51:95-99.

Drago, S.R., Valencia, M.E. (2004) Influence of components of infant formulas on in vitroiron, zinc and calcium availability, Journal of Agricultural and Food Chemistry 52(10):3202-3207.

FAO/WHO. (2002) Human Vitamin and Mineral Requirements. Food and Nutrition Division, Bangkok, 286s.

Fernández-García, E., Carvajal-Lérida, I., PérezGálvez, A. (2009) In vitro bioaccessibility assessment as a prediction tool of nutritional efficiency. Nutrition Research 29(11):751-760.

Freeland-Graves, J. H., Sanjeevi, N., Lee, J. J. (2015) Global perspectives on trace element requirements. Journal of Trace Elements in Medicine and Biology 31:135-141.

Frossard, E., Bucher, M., Mächler, F., Mozafar, A., Hurrell, R. (2000) Potential for increasing the content and bioavailability of $\mathrm{Fe}, \mathrm{Zn}$ and $\mathrm{Ca}$ in plants for human nutrition. Journal of the Science of Food and Agriculture 80(7):861-879.

Fuqua, B. K., Vulpe, C. D., \& Anderson, G. J. (2012). Intestinal iron absorption. Journal of Trace Elements in Medicine and Biology 26(2-3):115-11.

Galán, M.G., Drago, S.R. (2014) Food matriand cooking process affect mineral bioaccessibility of enteral nutrition formulas. Journal of the Science of Food and Agriculture 94(3):515-521.
Gregory, P. J., Wahbi, A., Adu-Gyamfi, J., Heiling, M., Gruber, R., Joy, E. J., Broadley, M. R. (2017) Approaches to reduce zinc and iron deficits in food systems. Global Food Security 15:1-10.

Güzel-Seydim, Z.B. (2016). Fonksiyonel Beslenme. Mineraller ve Fonksiyonel Etkileri. Sidas Yayınları, İzmir, 381 s.

Güzelcan, M. S., El, S. N. (2011) Simidin demir ve çinko mineralleriyle zenginleştirilmesi ve in vitro mineral biyoyararlılığının saptanması.Gıda 36(1): 41-48.

Hemalatha, S., Platel, K., Srinivasan, K. (2007a) Influence of heat processing on the bioaccessibility of zinc and iron from cereals and pulses consumed in India. Journal of Trace Elements in Medicine and Biology, 21(1):1-7.

Hemalatha S., Platel K., Srinivasan K. (2007b) Zinc and iron contents and their bioaccessibility in cereals and pulses consumed in India. Food Chemistry 102:1328-1336.

Hoppe, M., Önning, G., Berggren, A., Hulthén, L. (2015) Probiotic strain Lactobacillus plantarum 299v increases iron absorption from an iron-supplemented fruit drink: a double-isotope cross-over single-blind study in women of reproductive age. British Journal of Nutrition, 114(8):1195-1202.

Hunt, J. R. (2003) Bioavailability of iron, zinc, and other trace minerals from vegetarian diets. American Journal of Clinical Nutrition, 78(3):633-639.

Hurrell, R., Egli, I. (2010) Iron bioavailability and dietary reference values. The American Journal of Clinical Nutrition, 91(5):1461S-1467S.

Hurrell, R., Ranum, P., de Pee, S., Biebinger, R., Hulthen, L., Johnson, Q., Lynch, S. (2010) Revised recommendations for iron fortification of wheat flour and an evaluation of the expected impact of current national wheat flour fortification programs. Food and Nutrition Bulletin 31(11):7-21.

Khamoni, J. A., Hamshaw, T., Gardiner, P. H. (2017) Impact of ingredients on the 


\section{Demir Minerali: Fonksiyonları, Gıda İşlemenin Biyoyararlılığı Üzerine Etkileri ve Biyoaktif Bileşenler ile İnteraksiyonları}

elemental content of baby foods. Food Chemistry 231:309-315.

Kristensen, M. B., Hels, O., Morberg, C., Marving, J., Bügel, S., Tetens, I. (2005) Pork meat increases iron absorption from a 5-day fully controlled diet when compared to a vegetarian diet with similar vitamin $\mathrm{C}$ and phytic acid content. British Journal of Nutrition 94(1):78-83.

Kumar, V., Sinha, A. K., Makkar, H. P., Becker, K. (2010) Dietary roles of phytate and phytase in human nutrition: A review. Food Chemistry 120(4):945-959.

Kumar, S., Anukiruthika, T., Dutta, S., Kashyap, A. V., Moses, J. A., Anandharamakrishnan, C. (2020) Iron deficiency anemia: A comprehensive review on iron absorption, bioavailability and emerging food fortification approaches. Trends in Food Science \& Technology.

Kyomugasho, C., Gwala, S., Christiaens, S., Kermani, Z. J., Van Loey, A. M., Grauwet, T., Hendrickx, M. E. (2017) Pectin nanostructure influences pectincation interactions and in vitro bioaccessibility of $\mathrm{Ca} 2+, \mathrm{Zn} 2+, \mathrm{Fe} 2+$ and $\mathrm{Mg} 2+-$ ions in model systems. Food Hydrocolloids 62:299-310.

Lucca, P., Hurrell, R., Potrykus, I. (2001) Genetic engineering approaches to improve the bioavailability and the level of iron in rice grains. Theoretical and Applied Genetics 102(2-3):392-397.

Miret, S., Simpson, R. J., McKie, A. T. (2003) Physiology and molecular biology of iron absorption. Annual Review of Nutrition 23:283-301.

Moongngarm, A., Saetung, N. (2010) Comparison of chemical compositions and bioactive compounds of germinated rough rice and brown rice. Food Chemistry 122(3):782-788.

Mota C.,Nascimento A.C., Santos M., Delgado I., Coelho I., Rego A., Torres D.M., Castanheira I. (2016) The effect of cooking methods on the mineral content of quinoa (Chenopodium quinoa), amaranth (Amaranthus sp.) and buckwheat (Fagopyrum esculentum).
Journal of Food Composition and Analysi 49:57-64.

Murgia, I., Arosio, P., Tarantino, D., Soave, C. (2012) Biofortification for combating "hidden hunger" for iron. Trends in Plant Science 17(1): 47-55.

Navas-Carretero, S., Pérez-Granados, A. M., Schoppen, S., Vaquero, M. P. (2009) An oily fish diet increases insulin sensitivity compared to a red meat diet in young irondeficient women. British Journal of Nutrition 102(4):546-553.

Ortiz-Monasterio, J. I., Palacios-Rojas, N., Meng, E., Pixley, K., Trethowan, R., Pena, R. J. (2007) Enhancing the mineral and vitamin content of wheat and maize through plant breeding. Journal of Cereal Science 46(3):293-307.

Pavord, S., Myers, B., Robinson, S., Allard, S., Strong, J., Oppenheimer, C. (2012) UK guidelines on the management of iron deficiency inpregnancy. British Journal of Haematology 156(5): 588-600.

Perales, S., Barberá, R., Lagarda, M. J., Farré, R. (2006) Fortification of milk with calcium: effect on calcium bioavailability and interactions with iron and zinc. Journal of Agricultural and Food Chemistry 54(13):4901-4906.

Pereira, E. J., Carvalho, L. M., Dellamora-Ortiz, G. M., Cardoso, F. S., Carvalho, J. L. (2016) Effect of different home-cooking methods on the bioaccessibility of zinc and iron in conventionally bred cowpea (Vigna unguiculata L. Walp) consumed in Brazil. Food \& Nutrition Research 60(1): 29082.

Roldán-Marín, E., Sánchez-Moreno, C., Lloría, R., de Ancos, B., Cano, M. P. (2009) Onion high-pressure processing: Flavonol content and antioxidant activity. LWTFood Science and Technology 42(4):835841.

Rossi, E. (2005) Hepcidin - the iron regulatory hormone. Clinical Biochemist Reviews, 26:47-49.

Saini, R. K., Nile, S. H., Keum, Y. S. (2016) Food science and technology for management of iron deficiency in 


\section{Demir Minerali: Fonksiyonları, Gıda İşlemenin Biyoyararlılığı Üzerine Etkileri ve Biyoaktif Bileşenler ile İnteraksiyonları}

humans: A review. Trends in Food Science \& Technology 53:13-22.

Scholl, T. O. (2011) Maternal iron status: Relation to fetal growth, length of gestation and iron endowment of the neonate. Nutrition Reviews, 69(Suppl. 1): S23-29.

Sebastiá, V., Barberá, R., Farré, R., Lagarda, M. J. (2001) Effects of legume processing on calcium, iron and zinc contents and dialysabilities. Journal of the Science of Food and Agriculture 81(12):1180-1185.

Silva, J. G. S., Rebellato, A. P., Greiner, R., Pallone, J. A. L. (2017) Bioaccessibility of calcium, iron and magnesium in residues of citrus and characterization of macronutrients. Food Research International 97:162-169.

Singh, P., Prasad, S., Aalbersberg, W. (2016) Bioavailability of $\mathrm{Fe}$ and $\mathrm{Zn}$ in selected legumes, cereals, meat and milk products consumed in Fiji. Food Chemistry 207:125-131.

Thein, M., Ershler,W. B., Artz, A. S., Tecson, J., Robinson, B.E., Rothstein, G., Robbins, S. (2009) Diminished quality of life and physical function in community-dwelling elderly with anemia. Medicine (Baltimore) 88(2):107-114.

Vasconcelos, M., Grusak, M.A. (2006) Status and Future Developments Involving Plant Iron in Animal and Human Nutrition. Iron Nutrition in Plants and Rhizospheric Microorganisms (pp. 1-22). Springer, Dordrecht.

Countries (pp. 327-342). Humana Press, Totowa, NJ.
Vaquero, M. P., García-Quismondo, Á., Cañizo, F. J. D., Sánchez-Muniz, F. J., Kumar, A. (2017) Iron status biomarkers and cardiovascular risk. Recent Trends Cardiovasc Risks, 6: 97-117.

Walczyk, T., von Blanckenburg, F. (2002) Natural iron isotope variations in human blood. Science 295(5562): 2065-2066.

Welch, R. M., Graham, R. D. (2004) Breeding for micronutrients in staple food crops from a human nutrition perspective. Journal of experimental botany 55(396): 353-364.

Windisch, W. (2002) Interaction of chemical species with biological regulation of the metabolism of essential trace elements. Analytical and Bioanalytical Chemistry 372(3): 421-425.

Xia, Q., Wang, L., Xu, C., Mei, J., Li, Y. (2017) Effects of germination and high hydrostatic pressure processing on mineral elements, amino acids and antioxidants in vitro bioaccessibility, as well as starch digestibility in brown rice (Oryza sativa L.). Food Chemistry 214: 533-542.

Viadel, B., Barberá, R., Farré, R. (2006) Uptake and retention of calcium, iron, and zinc from raw legumes and the effect of cooking on lentils in Caco-2 cells. Nutrition Research, 26(11): 591596.

Yip, R. (2001) Iron deficiency and anemia. Nutrition and Health in Developing 